\title{
Latihan Menggenggam Alat Handgrip Menurunkan Tekanan Darah Pada Penderita Hipertensi
}

\author{
Sri Choirillaily ${ }^{1}$, Diah Ratnawati ${ }^{2 *}$ \\ ${ }^{1,2}$ Fakultas Ilmu Kesehatan, Universitas Pembangunan Nasional Veteran Jakarta \\ *Email: ratnawatidiah@yahoo.co.id
}

\begin{abstract}
Background: Hypertension is a serious health problem that is increasing every year. Lifestyle changes such as lack of movement become one of the factors developing this disease. This study was conducted to see the effectiveness gripping exercise of handgrip tool on changes in blood pressure in hypertension patients. Methods: The study used a method of quasi experiment pre and post test with one intervention group. This interventions was given to 16 adult respondents for 5 consecutive days. Assessment of the effectiveness of this therapy is done by measuring the respondent's blood pressure before and after the intervention. Results: The results showed that there was effectiveness gripping exercise of handgrip tool in on systolic blood pressure and diastolic blood pressure (p-value <0.05). So, gripping exercise of handgrip tool intervention can lower blood pressure in people with hypertension. Conclutions: The effectiveness of this therapy must also be done in conjunction with maintaining a lifestyle and regularly taking antihypertensive medication.
\end{abstract}

Keywords : adult, handgrip, hypertension

\section{PENDAHULUAN}

Dewasa merupakan seseorang yang berusia 18 tahun sampai 60 tahun, pada usia tersebut seseorang sudah pada tahap akhir pertumbuhan atau kekuatan yang sempurna (Efendi \& Makhfudli, 2013). Pada tahap dewasa akhir (40-60 tahun) dewasa akan mengalami penurunan fungsi fisiologis nya (Sudirjo \& Nur Alif, 2018). Ada banyak faktor risiko pada dewasa akhir yang membuat fungsi fisiologis semakin menurun. Beberapa faktor tersebut seperti, merokok, konsumsi garam berlebih, berat badan berlebih atau kegemukan, diet rendah serat, kurang aktivitas fisik, konsumsi alkohol, dislipidemia, dan stres.

Salah satu faktor yang memicu terjadinya penyakit tidak menular pada dewasa madya adalah kurangnya aktivitas fisik. Oleh karena itu, Kemenkes RI melalui gerakan masyarakat sehat merekomendasikan untuk masyarakat untuk melakukan aktifitas fisik sebanyak 3-5 kali dalam seminggu. Aktifitas fisik dapat dilakukan dengan baik, benar, terukur dan teratur. Aktifitas fisik yang teratur dapat mengurangi risiko penyakit tidak menular salah satunya hipertensi (Kemenkes RI, 2018).

Hipertensi atau nama lain dari tekanan darah tinggi merupakan tekanan darah sistolik $\geq 140 \mathrm{mmHg}$ dan tekanan darah diastolik $\geq 90 \mathrm{mmHg}$ pada pemeriksaan dua hari berbeda. Hipertensi disebut sebagai penyakit yang membunuh diam-diam karena menyebabkan kerusakan serius pada jantung. Pada kondisi hipertensi pasokan darah yang mengalir ke jantung mengalami penurunan. Hal tersebut yang menimbulkan kurangnya oksigen ke jantung dan mengakibatkan nyeri dada, serangan jantung bahkan gagal jantung. Penyakit ini juga menyebabkan kerusakan ginjal dan stroke bila tidak ditangani dengan tepat (WHO, 2019).

World Health Organization atau WHO (2019) menyebutkan sekitar 1,13 miliar jiwa menderita hipertensi atau dua 
pertiga penduduk dunia yang berasal dari kalangan kelas bawah dan menengah. Riset Kesehatan Dasar atau Riskesdas (2018) juga menyebutkan di Indonesia angka kejadian hipertensi mengalami kenaikan dari tahun 2013 yakni dari $25,8 \%$ menjadi $34,1 \%$. Kota di Indonesia dengan persentase kejadian hipertensi terbesar yakni di Kalimantan Selatan sebesar $44,1 \%$ dan persentase terkecil terjadi di Papua yakni 22,2\%. Survei Indikator Kesehatan Nasional atau Sirkesnas (2016) menunjukkan angka kejadian hipertensi usia 18 tahun ke atas mengalami peningkatan sebesar 32,4\% (Kemenkes RI, 2018). Berdasarkan Profil Kesehatan Provinsi Jawa Barat pada tahun 2017 didapatkan hasil khususnya di Depok terdapat 44.137 jiwa yang menderita hipertensi pada usia $\geq 18$ tahun dengan persentase $4,25 \%$. Persentase hipertensi yang meningkat tiap tahunnya menjadi masalah kesehatan yang harus dikendalikan untuk mencegah komplikasi hipertensi berlanjut yang berdampak pada kematian.

Pencegahan yang direkomendasikan oleh WHO (2019) dalam upaya mengurangi angka kejadian hipertensi meliputi pengendalian faktor risiko seperti, mengurangi asupan garam (kurang dari 5 gram setiap hari), konsumsi banyak buah dan sayuran, melakukan aktivitas fisik secara teratur, menghindari alkohol, merokok, dan membatasi makanan tinggi lemak. Oleh karena itu, melakukan aktivitas fisik yang teratur sangat dianjurkan sebagai strategi pencegahan dan promosi kesehatan. Andri dkk., (2018) menyebutkan aktivitas fisik yang teratur baik dalam usaha mengontrol tekanan darah. Aktivitas fisik yang dilakukan secara tepat dan teratur disebutkan memiliki pengaruh menurunkan prevalensi hipertensi hingga $50 \%$. Aktivitas yang menjadi salah satu perhatian untuk mengontrol tekanan darah adalah latihan menggenggam dengan alat handgrip. Latihan ini dikembangkan sebagai terapi potensial non farmakologis, walaupun pada awalnya latihan ini disebutkan dapat meningkatkan tenakan darah (Carlson dkk., 2016).

Latihan menggenggam alat handgrip merupakan bentuk latihan mengontraksikan otot tangan secara statis tanpa diikuti dengan pergerakan berlebih dari otot dan sendi. Efek latihan ini merangsang stimulus iskemik dan mekanisme shear stress akibat dari kontraksi otot pada pembuluh darah. Shear stress ini yang mengaktivasi Nitrit Oksida pada sel endotel yang dan dilanjutkan ke otot polos dengan cara berdifusi. Nitrit Oksida selanjutnya akan merangsang pengeluaran guanylate cyclase yang melebarkan pembuluh darah dengan merelaksasikan otot polos. Maka latihan ini akan melancarkan peredaran darah dan menurunkan tekanan darah tinggi (Andri dkk., 2018). Teori ini dibuktikan dalam penelitian Andri., dkk (2018) menyatakan bahwa latihan ini berpengaruh mengontrol tekanan darah pada pasien hipertensi di wilayah kerja Puskesmas Bukit Sari Bengkulu dengan nilai $\mathrm{p}$-value $<0,05$.

Pengaplikasian intervensi inovasi latihan menggenggam alat handgrip menjadi hal yang penting dalam menurunkan angka kejadian hipertensi. Salah satunya peran perawat sebagai pemberi asuhan keperawatan, role model dan agen perubahan. Peranan tersebut membantu melaksanakan inovasi latihan menggenggam alat handgrip dan mengembangkannya untuk menurunkan tekanan darah dengan cara non 
farmakologi. Pada peran pendidik kesehatan, perawat bertanggung jawab memberikan penyuluhan dalam menurunkan angka kejadian tekanan darah tinggi. Salah satunya dengan cara terapi inovasi pilihan latihan menggenggam alat handgrip.

Berdasarkan penyebaran kuesioner didapatkan warga sudah mengunjungi fasilitas kesehatan dan menggunakan obat tradisional untuk mengatasi penyakitnya. Namun, penanganan non-farmakologi dengan aktivitas fisik berupa latihan menggenggam alat handgrip masih jarang dilakukan, sedangkan angka kejadian hipertensi pada dewasa dan lansia mengalami peningkatan. Maka dari itu, peneliti melakukan sebuah penelitian tentang efektivitas intervensi inovasi latihan menggenggam alat handgrip dalam menurunkan tekanan darah pada penderita hipertensi.

\section{METODE PENELITIAN}

Penelitian ini menggunakan desain penelitian quasi experimental pre dan post test dengan satu kelompok intervensi. Teknik yang digunakan dalam penelitian ini adalah purposive sampling. Purposive sampling adalah sampel berdasarkan maksud pemilihan dan tujuan tertentu yang dikehendaki peneliti atau sesuai dengan kriteria yang ditetapkan peneliti.

Jumlah sampel dalam penelitian ini berjumlah 16 orang dengan menggunakan rumus federer. Kriteria inklusi pada penelitian ini adalah responden yang berusia 36-55 tahun dan memiliki tekanan darah lebih dari 140/90 $\mathrm{mmHg}$ setelah 2 kali pengukuran, sedangkan kriteria eksklusi penelitian adalah penderita hipertensi yang memiliki penyakit kronik seperti diabetes mellitus, gagal jantung, stroke, ataupun gagal ginjal dan memilki gangguan fungsional pada tangan.

Terapi ini menggunakan handgrip merek happyfit. Tahap pelaksanaan latihan ini dilakukan selama 5 hari dengan 1 kali intervensi setiap harinya. Setiap intervensi masing-masing tangan mendapatkan 2 kali kontraksi dengan durasi 45 detik. Gerakan melepaskan handgrip dilakukan selama 15 detik diantara 2 kontraksi tangan. Intervensi dilakukan dengan diawasi oleh peneliti setiap harinya. Pengukuran tekanan darah dilakukan setelah istirahat 30 menit.

\section{HASIL PENELITIAN Karakteristik Responden}

Karakteristik responden penelitian ada 3 variabel yaitu jenis kelamin, riwayat hipertensi, dan minum obat antihipertensi.

Tabel 1. Distribusi Frekuensi Karakteristik Responden Dewasa Hipertensi ( $\mathrm{n}=16)$

\begin{tabular}{lccc}
\hline Karakteristik & Kategori & $f$ & $\%$ \\
\hline \multirow{3}{*}{ Jenis Kelamin } & Pria & 1 & 6,25 \\
& Wanita & 15 & 93,75 \\
& Jumlah & 16 & 100,0 \\
\hline \multirow{2}{*}{ Riwayat Hipertensi } & Ada & 8 & 50,0 \\
& Tidak & 8 & 50,0 \\
& Jumlah & 16 & 100,0 \\
\hline \multirow{2}{*}{ Minum Obat } & Ya & 10 & 62,5 \\
Antihipertensi & Tidak & 6 & 37,5 \\
& Jumlah & 16 & 100,0 \\
\hline
\end{tabular}


Hasil analisis pada tabel 1 menunjukkan berdasarkan jenis kelamin menunjukkan dari 16 responden yang diteliti dapat diketahui bahwa 15 responden $(93,75 \%)$ dengan jenis kelamin wanita, dan sisanya sebanyak 1 responden $(6,25 \%)$ dengan jenis kelamin pria. Berdasarkan riwayat hipertensi dari keluarga menunjukkan dari 16 responden yang diteliti dapat diketahui bahwa 8 responden $(50 \%)$ dengan riwayat keluarga, dan sisanya sebanyak 8 responden (50\%) dengan tidak ada riwayat keluarga. Selain itu, berdasarkan minum obat antihipertensi menunjukkan dari 16 responden yang diteliti dapat diketahui bahwa 10 responden $(62,5 \%)$ minum obat antihipertensi, dan sisanya sebanyak 6 responden $(37,5 \%)$ tidak minum obat antihipertensi. Hasil analisis efektivitas latihan menggenggam alat handgrip terhadap tekanan darah tersaji dalam tabel 2.

Tabel 2. Tekanan Darah Sistolik Sebelum dan Sesudah Latihan Menggenggam Alat Handgrip $(n=16)$

\begin{tabular}{lcccc}
\hline Variabel & n & Mean & Std. Deviasi & P-Value \\
\hline $\begin{array}{l}\text { Tekanan Darah } \\
\text { Sistolik Sebelum }\end{array}$ & 16 & 146,25 & 7,188 & 0,000 \\
\hline $\begin{array}{l}\text { Tekanan Darah } \\
\text { Sistolik Sesudah }\end{array}$ & 16 & 140,31 & 6,945 & 0,000 \\
\hline
\end{tabular}

Berdasarkan hasil uji Wilcoxon responden adalah 140,31 dengan standar signed ranks pada tabel 2 didapatkan deviasi 6,945 yang menandakan tekanan rerata tekanan darah sistolik sebelum darah rerata responden menurun meskipun dilakukan latihan menggenggam alat masih pada kategori hipertensi derajat handgrip adalah 146,25 dengan standar satu. Hasil analisis statistik didapatkan deviasi 7,188 menandakan responden nilai p-value 0,000 maka dapat berada pada kategori hipertensi derajat disimpulkan terdapat efektivitas antara satu. Setelah dilakukan latihan latihan menggenggam alat handgrip menggenggam alat handgrip selama 5 hari dengan tekanan darah sistolik yang didapatkan rerata tekanan darah sistolik diberikan kepada 16 responden.

Tabel 3. Tekanan Darah Diastolik Sebelum dan Sesudah Latihan Menggenggam Alat Handgrip ( $\mathrm{N}=16)$

\begin{tabular}{lcccc}
\hline Variabel & n & Mean & Std. Deviasi & P-Value \\
\hline $\begin{array}{l}\text { Tekanan Darah } \\
\text { Diastolik Sebelum }\end{array}$ & 16 & 91,25 & 6,191 & 0,001 \\
\hline $\begin{array}{l}\text { Tekanan Darah } \\
\text { Diastolik Sesudah }\end{array}$ & 16 & 87,19 & 4,460 & 0,001 \\
\hline
\end{tabular}

Berdasarkan hasil uji paired t-test berada pada kategori hipertensi derajat pada tabel 3 didapatkan rerata tekanan darah diastolik sebelum dilakukan latihan menggenggam alat handgrip pada responden adalah 91,25 dengan standar deviasi 6,191 menandakan responden satu. Setelah dilakukan latihan menggenggam alat handgrip selama 5 hari, rerata tekanan darah diastolik pada responden adalah 87,19 dengan standar deviasi 4,460 yang menandakan tekanan 
darah menurun pada kategori pre hipertensi. Hasil analisis statistik didapatkan nilai $\mathrm{p}$ - value 0,001 berarti terdapat efektivitas yang signifikan antara latihan menggenggam alat handgrip dengan tekanan darah diastolik yang diberikan kepada 16 responden.

\section{PEMBAHASAN}

Penelitian ini menggunakan sampel sebanyak 16 responden yang memiliki masalah kesehatan tekanan darah tinggi diberikan berupa latihan menggenggam alat handgrip. Intervensi ini diberikan sesuai dengan hasil penelitian Andri, dkk. (2018) yang mengatakan bahwa latihan menggenggam alat handgrip dapat menurunkan tekanan darah tinggi. Tekanan darah tinggi salah satunya terjadi diakibatkan gangguan vasodilatasi pada endotel dikarenakan penurunan ketersediaan nitrit oksid (NO). Tekanan darah tinggi memiliki komplikasi yang berbahaya diantaranya dapat menyebabkan gagal jantung dan stroke.

Ramdhani, dkk. (2013) mengatakan pada usia 40 tahun ke atas akan rentan mengalami hipertensi karena pembuluh darah akan mengalami penebalan oleh tumpukan kolagen yang mengakibatkan penyempitan dan penurunan elastisitas. Pada umumnya, pertambahan usia akan menimbulkan banyak masalah kesehatan. Masalah kesehatan yang diderita merupakan akibat dari penurunan fungsi organ tubuh yang menyebabkan komplikasi. Terlebih orang dewasa saat ini memiliki gaya hidup yang tidak bagus, seperti suka makan makanan berpengawet, kurang aktifitas fisik, dan merokok. Hal tersebut dapat mempercepat kenaikan tekanan darah pada tiap tingkat kelompok umur.
Herbert Benson, dkk. (2012) juga mengatakan bahwa setelah masuk fase menopause, hormon estrogen dan progesteron pada perempuan akan menurun. Penurunan hormon estrogen menyebabkan peningkatan tekanan darah dikarenakan kadar High Density Lipoprotein (HDL) yang menurun. HDL yang rendah menjadi penyebab terjadinya proses aterosklerosis. Pada fase premenopause hormon estrogen yang melindungi kerusakan pembuluh darah akan berkurang kuantitasnya yang umumnya dimulai pada usia 45-55 tahun (Julius, 2008). Penyempitan dan penurunan elastisitas serta aterosklerosis akan meningkatkan tekanan darah yang memberikan efek salah satunya tengkuk terasa berat dan kepala pusing.

Peneliti memilih latihan menggenggam alat handgrip digunakan untuk menurunkan tekanan darah dan mengurangi efek dari tekanan darah tinggi. Latihan menggenggam alat handgrip merupakan intervensi dengan mengontraksikan otot tangan secara statis tanpa diikuti dengan pergerakan berlebih dari otot dan sendi. Pemberian latihan menggenggam alat handgrip selain dapat menurunkan tekanan darah tinggi, juga dapat mencegah atrofi otot, membangun volume otot, meningkatkan stabilitas sendi, serta mengurangi edema. Latihan menggenggam alat handgrip menggunakan alat handgrip untuk latihan aktivitas fisik. Latihan ini dengan cara mengontraksikan tangan dengan handgrip selama 45 detik dan istirahat 15 detik hingga setiap tangan mendapatkan 2 kali intervensi.

Latihan menggenggam alat handgrip efektif menurunkan tekanan darah dengan cara memperbaiki stres oksidatif dan peningkatan fungsi endotel pembuluh 
resistan. Umumnya pasien hipertensi mengalami gangguan vasodilatasi pada pembuluh darahnya. Salah satu penyebab gangguan vasodilatasi dikarenakan endotel yang kekurangan ketersediaan Nitrit Oksida. Nitrit Oksid merupakan Endothel Derived Releasing Factor (EDRF) yang bersifat vasodilator untuk mencegah pelekatan Low Density Lipoprotein. Pada permulaan latihan menggenggam alat handgrip dilakukan minimal 5 hari dalam satu minggu dengan durasi selama 180 detik sesuai dengan SOP terapi (Mortimer \& Mckune, 2011).

Implementasi latihan menggenggam alat handgrip yang dilaksanakan dalam waktu 5 hari pada responden menghasilkan penurunan tekanan darah dengan hasil pengukuran sebelum latihan hari ke-1 dan sesudah latihan hari ke-5. Hasil intervensi latihan menggenggam alat handgrip setelah 5 hari perlakuan didapatkan penurunan tekanan darah sistolik hingga sebesar $10 \mathrm{mmHg}$ dan penurunan tekanan darah diastolik sebesar $5 \mathrm{mmHg}$. Hasil ini membuktikan bahwa latihan menggenggam alat handgrip dapat menurunkan tekanan darah sesuai penelitian Andri, dkk. (2018) yang menyatakan terdapat pengaruh dari latihan menggenggam alat handgrip terhadap tekanan darah tinggi. Hasil analisis statistik diperoleh nilai $\mathrm{p}$-value 0.000 artinya terdapat efektivitas antara latihan menggenggam alat handgrip dengan tekanan darah sistolik, sedangkan hasil analisis statistik diperoleh nilai $p$-value 0.001 artinya terdapat efektivitas antara latihan menggenggam alat handgrip dengan tekanan darah diastolik.

Terapi ini lebih efektif bila dilakukan secara rutin dengan menjaga pola hidup. Pada dewasa terapi ini juga lebih mudah diaplikasikan karena terapi ini tidak memerlukan banyak ruang dan waktu, walaupun membutuhkan tenaga yang cukup untuk melakukan terapi. Hasil terapi pada setiap individu akan memiliki hasil yang berbeda yang dipengaruhi oleh usia, indeks massa tubuh, kebiasaan merokok, kebiasaan minum alkohol, serta riwayat keluarga. Oleh karena itu, faktorfaktor tersebut hendaknya menjadi perhatian untuk penderita hipertensi. Pada faktor risiko yang dapat diubah sebaiknya untuk dikurangi atau ditinggalkan sehingga tidak memperberat faktor risiko yang tidak dapat diubah (Made dkk, 2017).

Efektivitas latihan menggenggam alat handgrip terbukti dapat menurunkan tekanan darah. Ada beberapa faktor lainnya yang menyebabkan tekanan darah mengalami penurunan. Contohnya pada responden yang tergolong pasien hipertensi terkontrol dengan obat akan lebih mengalami efektivitas intervensi yang maksimal dibandingkan dengan responden yang tidak terkontrol. Pada faktor responden dengan minum obat terkontrol pun lebih efektif pada responden yang mengalami tengkuk berat, karena hal tersebut membuat responden patuh minum obat.

Faktor pendukung lain yang menyebabkan penurunan tekanan darah adalah terapi komplementer dengan mengonsumsi jus buah belimbing dan rebusan labu siam. Oleh karena itu, sangat diperlukan adanya kepatuhan minum obat anti hipertensi dan terapi komplementer yang sesuai untuk dapat mengontrol tekanan darah dan mencegah komplikasi hipertensi.

\section{KESIMPULAN DAN SARAN}

Hasil penelitian didapatkan latihan menggenggam alat handgrip dapat 
menurunkan tekanan darah sistolik dan diastolik. Intervensi ini lebih efektif bila dilakukan dengan faktor pendukung lainnya, seperti mengontrol hipertensi dengan minum obat, sadar akan kesehatan untuk mencegah komplikasi hipertensi, mengubah pola hidup, dan melakukan terapi komplementer untuk menurunkan tekanan darah.

\section{DAFTAR RUJUKAN}

Andri, J., Waluyo, A., Jumaiyah, W., \& Nastashia, D. (2018). Efektivitas Isometric Handgrip Exercise dan Slow Deep Breathing Exercise terhadap Perubahan Tekanan Darah pada Penderita Hipertensi. Jurnal Keperawatan Silampari. https://doi.org/10.31539/jks.v2i1.38 2

Carlson, D. J., Inder, J., Palanisamy, S. K. A., McFarlane, J. R., Dieberg, G., \& Smart, N. A. (2016). The efficacy of isometric resistance training utilizing handgrip exercise for blood pressure management: A randomized trial. Medicine (United States), 95(52). https://doi.org/10.1097/MD.000000 0000005791

Efendi, F., \& Makhfudli. (2013). Keperawatan Kesehatan Komunitas Teori dan Praktik dalam Keperawatan. Jakarta: Salemba Medika.

Herbert Benson, dkk. (2012). Menurunkan Tekanan Darah. Jakarta: Gramedia.

Julius, S. (2008). Clinical Implications of Pathophysiologic Changes in the Midlife Hypertensive Patients.
American Heart Journal, 886-891.

Kementerian Kesehatan Republik Indonesia. (2018). Faktor Risiko Hipertensi. Diakses dari http://p2ptm.kemkes.go.id/infograph ic-p2ptm/hipertensi-penyakitjantung-dan-pembuluh-darah/faktorrisiko-hipertensi

Kementerian Kesehatan Republik Indonesia. (2018). Potret Sehat Indonesia dari RISKESDAS 2018. Diakses dari https://doi.org/http://www.depkes.go .id/pdf.php?id=18110200003

Made, I. A., Widyanthari, D. M., \& Adnyana, M. O. (2017). Pengaruh Latihan Isometrik Terhadap Tekanan Darah Pasien Hipertensi. Community of Publishing in Nursing, 5 .

Mortimer, J., \& Mckune, A. . (2011). Effect of Short-term Isometric Handgrip Training on Blood Pressure in Middle-aged Females: Cardiovascular Topics. Cardiovascular Journal of Africa.

Dinas Kesehatan Provinsi Jawa Barat. (2017). Profil Kesehatan Provinsi Jawa Barat. Depok: Dinas Kesehatan Provinsi Jawa Barat

Ramdhani, R., Respati, T., \& Irasanti, S. N. (2013). Karakteristik dan Gaya Hidup Pasien Hipertensi di Rumah Sakit Al-Islam Bandung. Global Medical and Health Communication, 1.

Kemenkes RI. (2018). Hasil Utama RISKESDAS 2018. Jakarta: 
108 Jurnal Keterapian Fisik, Volume 5, No 2 , November 2020, hlm 62-145

Kementrian Kesehatan RI.

Sudirjo, E., \& Nur Alif, M. (2018).

Pertumbuhan dan Perkembangan

Motorik (Konsep Perkembangan

dan Pertumbuhan Fisik dan Gerak

Manusia). Sumedang: UPI

Sumedang Press.

WHO. (2019). Hypertension. Swiss:

World Health Organization 